\title{
Eyelid disorders: frequency of occurrence and profile of carriers in a Brazilian population sample
}

\author{
Alterações palpebrais: frequência de ocorrência e perfil \\ dos portadores em amostra populacional brasileira
}

Ana Cláudia Viana Wanzeler ${ }^{1}$, Marjorie Fornazier do Nascimento', Roberta Lilian Fernandes Sousa', Carlos Roberto

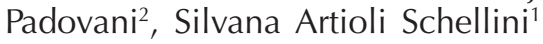

\begin{abstract}
Purpose: to show the frequency of occurrence of the eyelid disorders in a Brazilian population sample, as well as the characteristics of the carriers. Methods: a transversal study using a random population sample was carried out in the years 2004/2005, involving nine cities of the middle west region of the State of São Paulo - Brazil. We had 7654 participants which were evaluated according to demographic variables and complete ophthalmological examination. The eyelid disorders were detected using a lantern and slit lamp. Data were statistically analyzed. Results: eyelid disorders such as of trichiasis and ectropion were more related to the characteristics men, whites, complaining of reduced near visual acuity and $72.7 \%$ of trichiasis underwent surgical treatment, as well as $28.5 \%$ of patients with ectropion. Ptosis was related to the females, whites, complaining of reduced near visual acuity and $26.3 \%$ required surgery. Entropion was detected only in one case, male, white and a case of epiblepharon was observed in a female, brown. Conclusion: the most frequent palpebral disorder observed in the Brazilian general population is trichiasis, followed by ptosis and ectropion. The authors call attention to the fact that carriers do not have complaints related to the eyelid disorders.
\end{abstract}

Keywords: Eyelid diseases/epidemiology; Population studies; Brazil

\section{ReSUMO}

Objetivo: apresentar a frequência de ocorrência das alterações palpebrais em uma amostra populacional brasileira, assim como as características de seus portadores. Métodos: estudo transversal utilizando uma amostra populacional aleatorizada, realizado nos anos de 2004/2005, em nove cidades da região centro-oeste do estado de São Paulo. Foram examinadas 7654 pessoas sendo os participantes avaliados segundo variáveis demográficas e exame oftalmológico completo. As alterações palpebrais foram avaliadas por meio de exame externo usando lanterna e lâmpada de fenda. Os dados obtidos foram analisados estatisticamente. Resultados: as alterações palpebrais como a triquíase e o ectrópio foram mais relacionadas às características homens, brancos, queixa de redução de acuidade visual para perto. Foi realizado tratamento cirúrgico em $72,7 \%$ das triquíases detectadas, assim como $28,5 \%$ dos ectrópios. Já os casos de ptose palpebral, foram relacionados ao sexo feminino, brancos, com queixa de diminuição da acuidade visual para perto e 26,3\% necessitaram de cirurgia. Entrópio foi detectado em um caso, masculino, branco e epibléfaro foi observado em um indivíduo do sexo feminino, parda. Conclusão: a alteração palpebral mais presente na população geral brasileira é a triquíase, seguida da ptose palpebral e do ectrópio. Os autores chamam a atenção para o fato dos portadores não possuírem queixas relacionadas às alterações palpebrais.

Descritores: Doenças palpebrais/epidemiologia; Estudos populacionais; Brasil

\footnotetext{
${ }^{1}$ Faculdade de Medicina de Botucatu da Universidade Estadual Paulista "Júlio de Mesquita Filho", Botucatu, SP, Brazil.

2 Instituto de Biociências de Botucatu da Universidade Estadual Paulista "Júlio de Mesquita Filho", Botucatu, SP, Brazil.

Study conducted at the Medicine College of Botucatu - UNESP
}

The authors declare noconflicts of interest

Received for publication 07/10/2014 - Accepted for publication 16/03/2015

Rev Bras Oftalmol. 2015; 74 (4): 231-4 


\section{INTRODUCTION}

The eyelids are part of the protective mechanism of the eyes. They are structures composed of very delicate tissues that move constantly, with the possibility of undergoing changes due to external factors or alterations of senility, with the arisal of deformities ${ }^{1}$. They have sweat and sebaceous glands in their composition, besides the eyelashes which are differentiated hair follicles that grow with a convexity that takes them away from the eyes, so that the base of the follicle is closer and the end of it more distant to the eye bulb².

Keeping the eyelids opposite to the eye bulb is important for the integrity and distribution of the tear film. When there is eversion, inversion of the eyelid margin, or even loss of convexity of the eyelashes, the eye bulb suffers from failure of the protective mechanism, with the possibility of installation of inflammation and infections of the margin or the ocular surface, which highlights the importance normal positioning of the eyelids ${ }^{3}$.

There is no data on the presence and distribution of the eyelid position changes in the general population. But there is data available on the eyelid changes in convenience samples, as well as in the elderly, which led us to this study developed with the aim of describing the eyelid changes most commomly found in a randomized population sample, as well as the demographic characteristics of the patients.

\section{Methods}

Analyses were made on the eyelid position changes based on data from a cross-sectional study of a randomized population sample conducted between March 2004 and June 2005 in nine cities of the Midwest region of the state of São Paulo. The research protocol was analised and approved by the Research Ethics Committee of the Medicine College of Botucatu UNESP.

Participants were sorted taking into account the place of residence according to the IBGE census tract (Census, 2000). The sample size of 8,010 individuals was stablished, of which 7,654 people were examined. The sample size was based on the total number of inhabitants of the study area and on the prevalence of blindness and low vision in the population studied. The subjects were invited to participate and an appointment was scheduled with the approach of a Mobile Ophthalmic Unit.
Participants' identification data, clinical history, and ocular and systemic background were registered. Then a complete eye examination was performed with the assessment of visual acuity (VA) by means of the Snellen chart for the illiterate, external examination (using hand light), slit lamp examination in (Shin Nippon SL-203, Japan) and refractometry. For the present study a sub-sample of patients with eyelid changes was analyzed. When necessary, the subjects underwent surgical treatment.

Trichiasis was defined when there were lashes touching the eye, in that while deployed in the anterior lamella, they were abnormally curved and directed to eye surface ${ }^{4}$. Ectropion is the eyelid malpositioning characterized by the eversion of the eyelid margin away from the eye bulb. Eyelid entropion means reversing the edge of the eyelid, causing the eyelashes to touch the eyeball ${ }^{1}$. Ptosis is a condition in which the upper eyelid edge is located below its normal position of $2 \mathrm{~mm}$, covering the superior limbus in the primary position of the eye look $^{3}$.

The data was categorized and transferred to an Excel table, being statistically treated for the frequency analysis of occurrence of the phenomena observed.

\section{RESULTS}

The most significant change observed was the trichiasis, with 22 cases detected, and a frequency of occurrence of $0.29 \%, 59 \%$ being in men, $86.3 \%$ in white elderly, $63.6 \%$ with complaint of visual acuity reduction to near vision. Surgical treatment was necessary and performed in $72.7 \%$ of cases.

There were 19 cases of ptosis, with a frequency of occurrence of $0.24 \%, 63.1 \%$ in females, $84.2 \%$ in white elderly complaining of visual acuity (VA) reduction to near vision at $52.6 \%$, and $26.3 \%$ had surgery.

Ectropion was observed in 14 cases, with a frequency of occurrence of $0.18 \%, 78.5 \%$ in males, $100 \%$ white elderly with a main complaint of VA reduction to near vision $(50 \%)$ and ocular hyperemia $(42.8 \%)$ with the need of surgery in $28.5 \%$ of cases.

Entropion was detected in one case in a white male, and one case of epiblepharon in a brown female (Table 1). The frequency of occurrence of these two conditions was $0.01 \%$.

For all the conditions detected except ptosis the lower eyelid was the most affected.

Table 1

Frequency of occurrence of eyelid changes in the Midwest region of the State of São Paulo, Brazil.

\begin{tabular}{lccccc}
\hline Change & $\mathbf{N}^{\mathbf{0}}$ cases & Sex & Skin color & Complaints & Surgical treatment \\
\hline Ectrópio & 14 & $78.5 \%$ males & $100 \%$ white & BAV PP $(50 \%) /$ Hyperemia $(42.8 \%)$ & $28.5 \%$ \\
Ptose & 19 & $63.1 \%$ females & $84,2 \%$ white & $52.6 \%$ BAV PP & $26.3 \%$ \\
Triquíase & 22 & $59 \%$ males & $86.3 \%$ white & $63.6 \%$ BAV PP & $72.7 \%$ \\
Entrópio & 1 & $100 \%$ males & $100 \%$ white & $100 \%$ whatery eyes & $0 \%$ \\
Epibléfaro & 1 & $100 \%$ females & $100 \%$ brown & BAV PP and Hyperemia & $0 \%$ \\
\hline
\end{tabular}




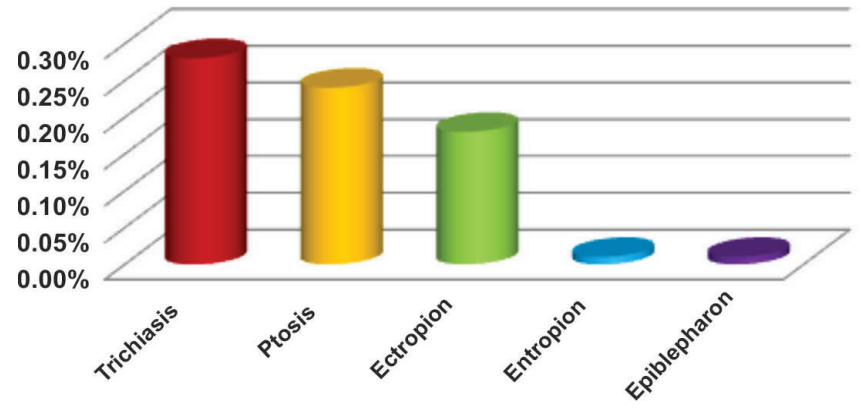

Figure 1: Frequency of occurrence of eyelid changes in inhabitants of the Midwest region of the State of São Paulo - Brazil

\section{Discussion}

The main value of the present study was that the evaluation was performed in a randomized population sample, which allowed us to know the frequency of occurrence of eyelid position changes in the general population without considering convenience samples. Knowing the frequency of occurrence of eyelid changes is interesting due to characteristics of individuals living in a given area, as it is important to plan the training for residency programs.

The most frequent change found in the eyelids was trichiasis, which is an acquired condition usually due to chronic inflammation of the eyelid margin as blepharitis and meibomites, cicatrization conjunctival diseases and cicatrization anomalies of the eyelid margin associated or not to previou surgeries ${ }^{4}$. Dermatoses as well as the effect of solar radiation on the delicate skin of the lower eyelid are also important ${ }^{2}$ with the coincidence of trichiasis being observed primarily in white men who probably worked exposed to the sunlight, as the area under study is primarily agricultural. Another cause of trichiasis and entropion is trachoma, which was very prevalent in the rural area of São Paulo at the beginning of last century, with the characteristic of affecting the upper eyelid where the tarsal plate is wider and being reported that the disease is more frequent in women ${ }^{5,6}$.

Ptosis was observed in $0.24 \%$ of the study population, predominantly in females and white people. The prevalence of ptosis in another region was higher than that observed in the present study ${ }^{7}$, probably due to the presence of older patients in that group of patients or the type of selection that was proposed for the studies. There is no sufficient data available about the frequency of occurrence of ptosis, but it is known that there is equal frequency among different races and between sexes ${ }^{8}$. The surgery was performed in only $26.3 \%$ of patients with ptosis. Surgical treatment is mandatory only in severe ptosis which can lead to serious functional deficit ${ }^{9}$.

Ectropion corresponds to the lower eyelid eversion and may be due to congenital or acquired causes, and the involutional type is the most frequent one ${ }^{10}$. A study involving only the elderly in São Paulo pointed out the prevalence of ectropion in $2.9 \%$ of cases, whereas in the general population we found ectropion in $0.18 \%$. It was found mostly in males and white people, with the consensus that men are more prone to eye disorders, perhaps due to having professions in which they are more exposed to risk factors ${ }^{11}$. Several patients with ectropion $(42.8 \%)$ had ocular hyperemia, which can be explained by the concomitance of meibomitis, blepharitis and keratitis with the ectropion position of the eyelid ${ }^{2,12}$. However, the surgery was performed in only $28.5 \%$ of cases, most likely due to the non-adherence to surgical treatment of patients who did not have great complaints.

Regarding entropion, the frequency of occurrence was $0.01 \%$, while an entropion of $2.1 \%$ have been found when assessing only the elderly. The involutional entropion is the most frequent, and affects only the lower eyelid ${ }^{14}$.

The epiblepharon is clearly influenced by race, being much more frequent in Japanese children, with a prevalence of $4.3 \%$, with no sex preference, with lower eyelids affected and bilateral involvement ${ }^{15}$. It is rare in our country, being detected in $0.01 \%$ of the study participants. By representing a skin fold, most often in the lower eyelid and pushing the eyelashes against the eye bulb $^{2}$ which can be reduced with the growth of the face in general, surgery is not necessary, as it happened to the subject who was part of this study.

It is very important to point out that the vast majority of patients with eyelid position changes complained only about concomitant refractive errors, which values the need for comprehensive eye exams.

\section{Conclusion}

The most present eyelid change in the general population of a region of São Paulo, Brazil was trichiasis, followed by ptosis and ectropion. The authors emphasize the fact that patients have no complaints about the changes of the eyelid position.

\section{REFERENCES}

1. Schellini AS, Zimmermann GPM, Hoyama E, Padovani CR, Padovani CRP. Alterações da margem palpebral associadas ao ectrópio. Arq Bras Oftalmol. 2005; 68(5):619-22.

2. Matayoshi S, Forno EA, Moura EM. Manual de cirurgia plástica ocular. São Paulo: Roca; 2004.

3. Vital Filho J, Cruz AA, Schellini AS, Matayoshi S, Figueiredo AR, Herzog Neto G. Órbita, sistema lacrimal e oculoplástica. 3a ed. Rio de Janeiro: Cultura Médica, Guanabara Koogan; 2013.

4. Hirai FE, Shiguematsu AI, Schellini SA, Padovani CR. Tratamento cirúrgico da triquíase maior. Rev Bras Oftalmol. 1998;57(5):357-61.

5. Muñoz B, Bobo L, Mkocha H, Lynch M, Hsieh YH, West S. Incidence of trichiasis in a cohort of women with and without scarring Int J Epidemiol.1999, 28(6):1167-71.

6. Khandekar R, Mohammed AJ. The prevalence of trachomatous trichiasis in Oman (Oman eye study 2005). Ophthalmic Epidemiol. 2007, 14(5):267-72.

7. Van-Langston D. Manual de oftalmologia: diagnóstico e tratamento. 4a ed. Rio de Janeiro: Ed Medsi; 2001.

8. Finsterer J. Ptosis: causes, presentation, and management. Aesthet Plast Surg. 2003;27(3):193-204.

9. Soares EJ, Figueiredo AR, Souza GL, Almeida HC, Oliveira LR, Magalhães MM, Portellinha WM. Blefaroptose. In: Soares EJ, Moura EM, Gonçalves JOR, ed. Cirurgia plástica ocular. São Paulo: Rocca; 1997. p.77-152.

10. Cruz AA, Chahud F, Guimarães FC. Patologias dos anexos oculares. Medicina(Ribeirão Preto). 1997;30(1):36-51. 
11. Romani FA. Prevalência de transtornos oculares na população de idosos residentes na cidade de Veranópolis - RS, Brasil. Arq Bras Oftalmol. 2005;68(5):649-55.

12. Veloso CE, Schellini SA, Padovani CR, Padovani CR. Ectrópio palpebral: características e relação com alterações óculopalpebrais. Rev Bras Oftalmol. 2006;65(3):147-51.

13. Damasceno RW, Osaki MH, Dantas PE, Belfort Jr R. Involutional entropion and ectropion of the lower eyelid: prevalence and associated risk factors in the elderly population. Ophthal Plast Resconstr Surg. 2011;27 (5): 317-20.

14. Kersten RC, Hammer BJ, Kulwin DR. The role of enophthalmos in involutional entropion. Ophthal Plast Reconstr Surg. 1997;13(3):195-8
15. Hayasaka Y, Hayasaka S. Epiblepharon with inverted eyelashes and high body mass index in Japanese children. J Pediatr Ophthalmol Strab. 2005;42 (5):300-3.

\section{Corresponding author:}

Ana Cláudia Viana Wanzeler

Rua Antônio Amando de Barros, 241 - Botucatu (SP)

ZIP Code: 18601-260

Email: anclaudiavw@yahoo.com.br 